\title{
UKRAINIAN BANKS SUSTAINABLE DEVELOPMENT RESEARCH AND MANAGEMENT CONCEPT
}

\section{Stanislav Ustenko}

Prof. DSc, Kyiv National Economic University named after Vadym Hetman, e-mail: stasustenko@ukr.net, orcid.org/0000-0001-6742-3575, Ukraine

\section{Inviia Hivarhizov}

MA, Kyiv National Economic University named after Vadym Hetman, e-mail: hevarhizov.inviya@gmail.com, orcid.org/0000-0002-6196-2743, Ukraine

\begin{abstract}
The article proposes conceptual and methodological principles of research of the banks sustainable development processes for evaluation of efficiency and decision making. The measures undertaken by banks to ensure their development and security are not systematic in nature aimed exclusively at protecting against individual threats, which ultimately does not provide the required level of banking security. The concept of research on the processes of sustainable development of banks is based on the general principles of development of the banks formation with the main ones being the principles of integrity, sustainability, digitalization and structural logical connection of the elements and the banking system as a whole.
\end{abstract}

Keywords: efficiency, optimization, information technologies, fuzzy model, digitalization, closed structural and technological cycle, finance.

\section{DOI: http://dx.doi.org/10.23856/3703}

\section{Introduction}

The article proposes the Concept of research of the banks sustainable development processes, which aims at systematization, development, formation and definition of methodological principles for estimating efficiency of sustainable development of Ukrainian banks, based on the general analysis, principles of development, formation of banks in conditions of sustainable development of commercial banks and the use of structuraltechnological features of the banking system in Ukraine, development of a fuzzy model for evaluating the banks efficiency, modeling of decision-making processes and implementation of controlling and monitoring subsystems in the structure of the management system of decision-making. The concept of research of banks sustainable development processes is based on the general principles of development of the formation of banks including the principles of integrity, sustainability, digitization and structural logical connection of the elements and the banking system as a whole. This approach allows us to implement a modified closed-loop cycle of banking product development in an integrated banking environment interconnected between participants in monetary transactions.

\section{Banking Sustainability Research Concept}

The development of new models and methods for researching the banks' sustainable development processes aims to form a new Concept for the Study of Banks Sustainable Development (hereinafter the Concept), which is focused at systematization, implementation 
of principles and consistent approaches of forming the direction of the banks sustainable development and making effective management decisions.

The implementation of such a Concept creates opportunities for increasing the level of banks stability by defining the methodological foundations of banking processes, a comprehensive approach to the study of the processes of creating sustainable development of banks and the use of structural and technological features of the banking system, modeling decision-making processes for banks sustainable development, search for dynamic and flexible methods for managing processes and projects in banks.

The basis of the proposed Concept is the methodology of research of banks sustainable development, which consists of five blocks, the implementation of which is carried out by solving specific scientific problems and applied problems in the respective blocks in Figure. 1.

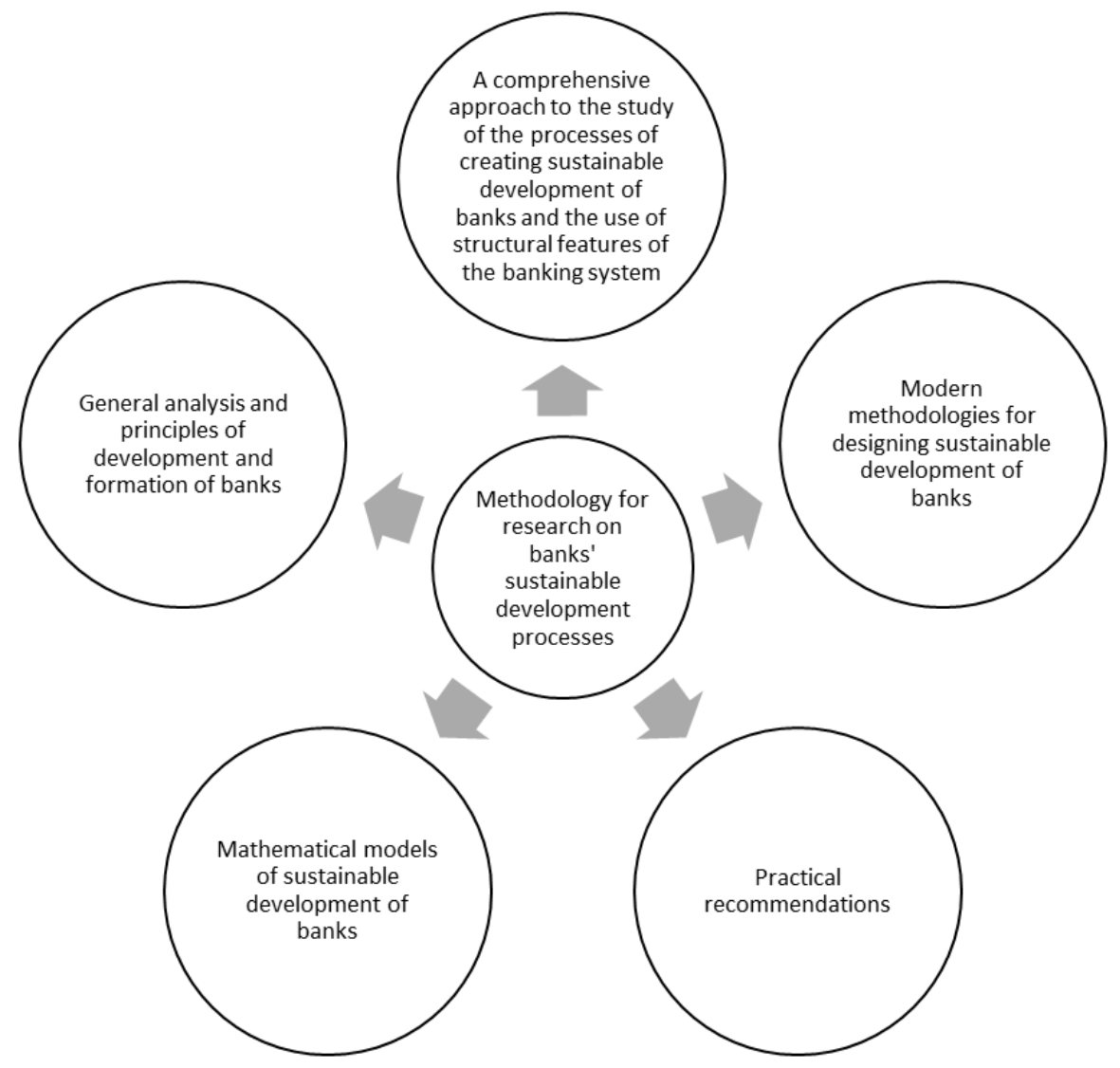

Figure 1. The banks sustainable development research concept

The initial stage of the study is to identify the tools and set of research methods, which are based on a comprehensive study and determine the principles of banks' sustainability.

In the conditions of development of banks, sustainability is such a property of the development of a system as a public structure, which is illustrated by the increase of reproduction of its activity from the quantitative and qualitative aspect in accordance with social requirements. 


\section{Analysis and principles of sustainable development and formation of banks}

In a conceptual sense, managing sustainable development of banks should begin by defining a methodology for the study of banks' sustainable development, based on a general analysis and principles of development of bank formation, which has a number of characteristics invariant to the goals of the study, among which the main ones are the following:

1) Integrity - the elements of the system are subordinated to the sole purpose of meeting the needs of participants in the economic processes of the country.

2) Resilience - the ability to counteract internal and external disturbances other than the calculated ones, as well as to overcome unforeseen disturbances in the operating environment with relatively minimal damages and loss of functionality;

3) Digitalization - has a goal to move to automated digital production, managed by intelligent real-time systems in constant interaction with the external environment.

4) Structural logic of connections - thoughtful and structurally-ordered connections between elements of the system;

5) Balance - focus on coverage of all aspects of the bank's activities and the relationship between these aspects as well as on the change of the situation outside and inside the bank;

6) Equilibrium - the desire to achieve the highest possible level of satisfaction of needs as a result of the activity of all market participants;

7) Multicriteriality - response to a changing environment by moving to well-founded and identified alternatives;

8) Causality - ability to changes, which are implemented in a certain order, taking into account the achieved results and specific features of processes and phenomena;

9) Uncertainty in operation - the impact of external disturbances and responses to them;

10)Adaptability - the ability to adapt to systematic changes to meet the goals of banks.

A comprehensive approach to the study of the processes of creating banks sustainable development is orientated at the construction of the process of sustainable development as a holistic development of all processes, rather than its individual processes, which contributes to the bank's overall development. The main approaches to creating the banks sustainable development include:

1) Closed structural-technological cycle (CSTC);

2) Legislative framework - a system of legal rules in which the bank must operate;

3) Digitalization is an element of the information field of development and scaling of the bank's activity.

In order to define more precisely the methodological principles for bank sustainable development processes, a modified (CSTC) banking product development has been implemented in an integrated banking environment that is interconnected between participants in monetary transactions.

The industry uses such a typical closed production and technological cycle (CPTC) (Ustenko, 2008).

The main idea behind the introduction of CSTC in banks is to reuse the resource which, in combination with information technology, provides the necessary quality for the development of a banking product. The first stage in the life cycle of a product is research and 
development work aimed at acquiring new knowledge and their practical application in creating a new product or technology.

At the second stage of product life cycle, the task is to develop and find the most effective ideas for introducing a banking product. The stage of future product analysis aims at examining the needs and goals to obtain the highest possible level of satisfaction of people's needs as a result of the activity or use of this product. After analyzing the future product, the development stage of the banking product begins, and it includes finding successful developments in the implemented similar products. The main purpose of the stage of management and marketing processes of banking development is to attract more users. It is recommended to use flexible product development methodologies (Ward Cunningham, 2001). The last stage is the maintenance of this product in the conditions of the CPTC if there are already existing techniques for the maintenance of such a product they are taken as a basis for modification for a new product.

The essence of the legislative framework is to regulate public relations between participants in the banking system by developing legal rules and laws.

Optimization and adjustment of this approach gives such positive opportunities for sustainable development of banks as precision in the interpretation of the legal framework, clarity and transparency.

Digitalization as an approach for the sustainable development of banks involves the transformation of all analog and outdated processes of banks into new, current products of consumer demand using the latest technology.

To solve economic and mathematical problems in the context of the sustainable development of banks, a group of the so-called weakly structured problems based on fuzzy set theory should be used.

A fuzzy model for assessing the sustainable development of banks is proposed, which embodies the construction of fuzzy knowledge of the object of identification that is expertly formed, as well as a mechanism for drawing a logical conclusion based on the use of a mathematical apparatus of fuzzy set theory.

The fuzzy model analyzes groups of performance indicators of financial, economic, personnel and information and intellectual subsystems of the bank, and uses an algorithm of five stages of development (Matviychuk, 2007; Olkhovska, 2011).

\section{Stage 1. Selection of the metrics to be considered in the model}

The financial and economic subsystem performance evaluation unit includes the following indicators:

- Return on bank assets;

- Return on the bank equity;

- The level of the bank's efficiency;

- Net spread;

- Net interest margin;

- Asset turnover;

- Average assets balance.

The HR subsystem efficiency evaluation block includes the following indicators:

- Net income per employee;

- Net income to staff costs. 
- The information-intellectual subsystem efficiency evaluation block has the following indicators:

- Efficiency of marketing;

- The ratio of bank involvement in digitalization.

\section{Stage 2. Description of the variables to be considered in the model}

The output parameter or the integral performance indicator is calculated on the basis of the estimation of the parameters of financial and economic $\left(E_{1}\right)$, personnel $\left(E_{2}\right)$ and information- intellectual $\left(E_{3}\right)$ subsystems of sustainable development of banks (Zade, 1976).

$$
R=f\left(E_{1 \ldots} \ldots E_{m}\right), E_{i}=f\left(E_{1 i \ldots} \ldots E_{n i}\right), i=\overline{1, m}, j=\overline{1, n}
$$

To reflect the relationship between input and output parameters, we form the linguistic characteristics of the qualitative terms of the financial, economic, personnel and informationintellectual subsystems of sustainable development of banks, $\{Д H, H, C, B, Д B\}$ where VL is very low, $\mathrm{L}$ is low, $\mathrm{M}$ is medium, $\mathrm{H}$ is high, $\mathrm{VH}$ is very high. The resulting parameter $R$ gives an opportunity to estimate the level of sustainable development on the following scale of term-sets $\{\Pi, 3, H 3, K\}: \mathrm{P}$ - positive, $\mathrm{S}$ - satisfactory, US - unsatisfactory, C-critical.

\section{Stage 3. Definition of types and construction of membership function}

Suppose that there exists some universal set $L$ (which includes a set of possible values of the $i$-i variable), then there is a fuzzy subset $U$ that describes the constraints on the possible values of variable $p_{i s}$ Then $U$ can be defined as:

$$
U=\left\{E_{i j}, \mu^{p_{*}^{0}}\left(E_{i j}\right) ; E_{i j} \in L\right\} \text { та } U=\left\{E_{i j}, \mu^{p^{\circ}}\left(E_{i}\right) ; E_{i} \in L\right\}
$$

\section{Stage 4. Building a fuzzy knowledge base}

Let us form a set of rules - a fuzzy knowledge base, which is expert-logical conclusion for the basic evaluation criteria for evaluating subsystem states. An example of the rules for a positive overall level of sustainability assessment performance can be formulated as follows:

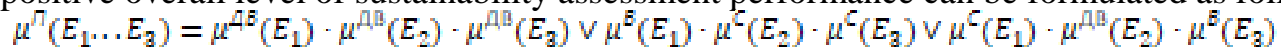

\section{Stage 5. Adjusting the model parameters and determine the output characteristics}

At the final stage of building a model for assessing the efficiency of banks' sustainable development, we will determine the options for setting up the system and drawing a logical conclusion. To express the degree of association between the output variable and the input variables, the function of assigning the input variables $E_{i}$ to the value of the output variable $R$ can be represented as:

$$
\mu^{g^{k}}\left(E_{1}, E_{2}, E_{3}\right)=\bigvee_{p=1}^{3} \times\left[\bigwedge_{i *=11}^{3} \times \mu^{p_{i}^{0}}\left(E_{i}\right)\right]
$$

By analyzing the performance of the above subsystems, you can assess the reasonableness of the model developed. Determining the level of efficiency of the banks sustainable development is based on the Fuzzy logic of Mamdani-type algorithms, as one of the most common fuzzy inference methods. 
According to statistics obtained from the open sources of the National Bank of Ukraine (National Bank of Ukraine, 2019) given in Table 1, input variables $E_{1}, E_{2}, E_{3}$ for the five surveyed banks were calculated.

The graphs of fuzzy terms for the Mamdani algorithm are shown below (Figure 2-5.):

- for the parameter of the integral indicator of efficiency of bank activity:

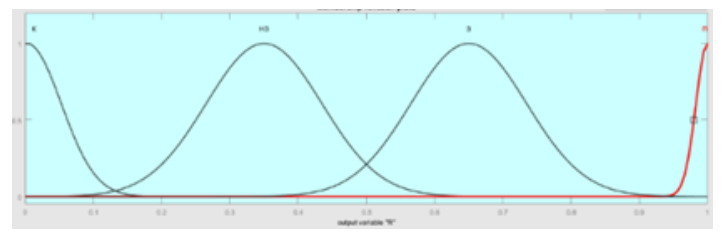

Figure 2. Parameters of $R$ indicator

- for the parameters of the block of efficiency evaluation of the financial-economic subsystem:

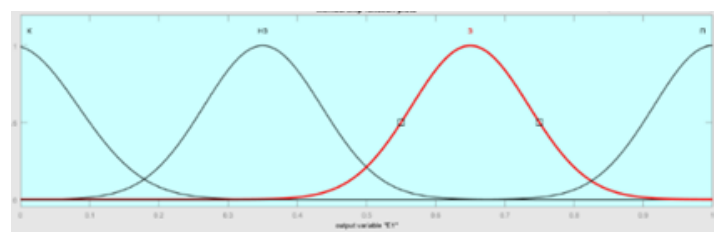

Figure 3. Parameters of $E_{1}$ indicator

- for the parameters of the block evaluation of the personnel subsystem efficiency:

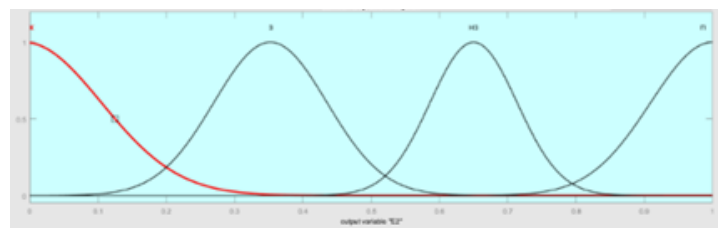

Figure 4. Parameters of $E_{2}$ indicator

- for the parameters of the block evaluation of the information and intellectual subsystem efficiency:

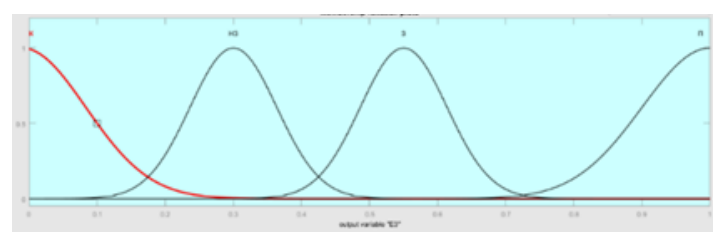

Figure 5. Parameters of $E_{3}$ indicator

Observing these charts of fuzzy terms, it is possible to note that some graphs have different density of values, which is necessitated by the observance of some normative values 
for a number of indicators (marketing efficiency ratio $<0.5$; interest margin ratio $>1$; bank efficiency ratio $>2$ ). Therefore, the labeled regulatory data was taken as the middle row of the distribution and the grouping of the data sets of indicators was relative to the lower boundary and the average and middle and upper boundaries of the indicators.

We simulated the processes of modeling evaluation of work conditions of such banks as: JSC "Ukreximbank", PJSC "First Ukrainian International Bank", JSC "TASCOMBANK", PJSC "Trust-capital", JSC "Privatbank".

Table 1 shows the results of the calculations of the parameters for evaluating the efficiency of the financial and economic subsystem of these banks by analytical means.

Table 1

\section{The results of the calculations}

\begin{tabular}{|c|c|c|c|c|c|c|c|c|c|c|c|c|c|}
\hline \multirow{3}{*}{$\begin{array}{l}\text { The name of } \\
\text { the } \\
\text { coefficients }\end{array}$} & \multicolumn{10}{|c|}{ Indicators } & \multirow{3}{*}{$\begin{array}{c}\text { Norma- } \\
\text { tive value }\end{array}$} & \multirow{3}{*}{$\begin{array}{c}\begin{array}{c}\text { Mini- } \\
\text { mum for } \\
\text { banks }\end{array} \\
\text { value }\end{array}$} & \multirow{3}{*}{$\begin{array}{c}\text { Maxi } \\
\text {-mum } \\
\text { for } \\
\text { banks }\end{array}$} \\
\hline & \multicolumn{2}{|c|}{$\begin{array}{c}\text { JSC } \\
\text { Ukreximbank }\end{array}$} & \multicolumn{2}{|c|}{$\begin{array}{l}\text { PJSC "First } \\
\text { Ukrainian } \\
\text { International } \\
\text { Bank" }\end{array}$} & \multicolumn{2}{|c|}{$\begin{array}{c}\text { JSC } \\
\text { "TASCOMBA } \\
\text { NK" }\end{array}$} & \multicolumn{2}{|c|}{$\begin{array}{l}\text { PJSC } \\
\text { "Trust- } \\
\text { capital" }\end{array}$} & \multicolumn{2}{|c|}{$\begin{array}{c}\text { JSC } \\
\text { "Privatbank" }\end{array}$} & & & \\
\hline & value & $\begin{array}{l}\text { conclu- } \\
\text { sion }\end{array}$ & $\begin{array}{c}\text { valu } \\
e\end{array}$ & $\begin{array}{l}\text { conclu- } \\
\text { sion }\end{array}$ & value & $\begin{array}{l}\text { conclu- } \\
\text { sion }\end{array}$ & $\begin{array}{c}\text { valu } \\
e\end{array}$ & $\begin{array}{l}\text { conclu- } \\
\text { sion }\end{array}$ & $\begin{array}{c}\text { valu } \\
e\end{array}$ & $\begin{array}{c}c \\
\text { conclu- } \\
\text { sion }\end{array}$ & & & \\
\hline \multicolumn{14}{|c|}{ financial-economic subsystem efficiency evaluation block } \\
\hline \multirow{2}{*}{$\begin{array}{l}\text { Return on } \\
\text { bank assets }\end{array}$} & 0,0058 & VL & 0,024 & VL & 0,010 & VL & 0,002 & VL & 0,040 & VL & $>0,015$ & 0,002 & 0,040 \\
\hline & 0,011 & VL & 0,03 & VL & 0,011 & VL & 0,005 & VL & 0,124 & $\mathrm{~L}$ & $>0,005$ & 0,005 & 0,124 \\
\hline \multirow{2}{*}{$\begin{array}{l}\text { Return on } \\
\text { the bank's } \\
\text { equity }\end{array}$} & 0,142 & $\mathrm{~L}$ & 0,193 & $\mathrm{~L}$ & 0,084 & $\mathrm{~L}$ & 0,003 & $\mathrm{~L}$ & 0,517 & $\mathrm{H}$ & $>0,18$ & 0,003 & 0,517 \\
\hline & 0,031 & $\mathrm{VL}$ & 0,565 & M & 0,204 & $\mathrm{~L}$ & 0,005 & VL & 0,102 & $\mathrm{~L}$ & $>0,18$ & 0,005 & 0,565 \\
\hline $\begin{array}{l}\text { Level of the } \\
\text { bank's } \\
\text { efficiency }\end{array}$ & 0,494 & M & 0,786 & $\mathrm{H}$ & 0,270 & $\mathrm{~L}$ & 0,084 & VL & 2,958 & $\mathrm{VH}$ & $>0,8$ & 0,084 & 2,958 \\
\hline Net spread & 0,051 & VL & 0,063 & VL & 0,046 & VL & 0,003 & VL & 0,087 & L & $>0,05$ & 0,003 & 0,087 \\
\hline $\begin{array}{l}\text { Net interest } \\
\text { margin }\end{array}$ & 0,530 & L & 1,245 & $\mathrm{H}$ & 0,881 & M & 0,790 & M & 1,608 & $\mathrm{H}$ & $>0,8$ & 0,530 & 1,608 \\
\hline $\begin{array}{l}\text { Asset } \\
\text { turnover }\end{array}$ & 0,011 & $\mathrm{VL}$ & 0,037 & VL & 0,013 & VL & 0,006 & VL & 0,124 & $\mathrm{~L}$ & $>0,038$ & 0,006 & 0,124 \\
\hline $\begin{array}{l}\text { Average } \\
\text { assets } \\
\text { balance }\end{array}$ & 0,624 & $\mathrm{H}$ & 0,120 & $\mathrm{~L}$ & 0,295 & $\mathrm{~L}$ & 0,980 & $\mathrm{VH}$ & 0,089 & $\mathrm{~L}$ & $>0,5$ & 0,089 & 0,980 \\
\hline \multicolumn{14}{|c|}{ HR subsystem efficiency block } \\
\hline $\begin{array}{l}\text { Net income } \\
\text { per } \\
\text { employee }\end{array}$ & 0,381 & L & 0,218 & L & 0,130 & VL & 0,015 & $\mathrm{VL}$ & 0,833 & vH & $>0,31$ & 0,015 & 0,833 \\
\hline $\begin{array}{l}\text { Net income } \\
\text { to staff costs }\end{array}$ & 0,029 & $\mathrm{VL}$ & 0,017 & $\mathrm{VL}$ & 0,025 & VL & 0,011 & $\mathrm{VL}$ & 0,019 & VL & $>0,021$ & 0,011 & 0,029 \\
\hline \multicolumn{14}{|c|}{ information-intellectual subsystem efficiency block } \\
\hline $\begin{array}{l}\text { Marketing } \\
\text { efficiency } \\
\text { ratio }\end{array}$ & 0,001 & L & 0,038 & M & 0,046 & M & 0 & $\mathrm{VL}$ & 0,0005 & L & $>0,02$ & 0 & 0,046 \\
\hline $\begin{array}{l}\text { Ratio of } \\
\text { bank } \\
\text { involvement } \\
\text { in } \\
\text { digitalization }\end{array}$ & 0,276 & $\mathrm{H}$ & 0,261 & $\mathrm{H}$ & 0,998 & VL & 5,231 & $\mathrm{VL}$ & 0,077 & VH & $>1.5$ & 0,077 & 5,231 \\
\hline
\end{tabular}

Analyzing the indicators of different banks, we can see that the performance indicators in different blocks of subsystems have some sign of volatility, which tells us about the process of formalization of banks after the banking reform that started in 2014.

The results of the model show us that for Ukreximbank positive data in Block $E_{1}$ are the level of bank efficiency and average assets balances. Block $E_{2}$ has a very low level of net 
income for staff costs. Block $E_{3}$ demonstrates a high ratio of the bank's involvement in digitalization.
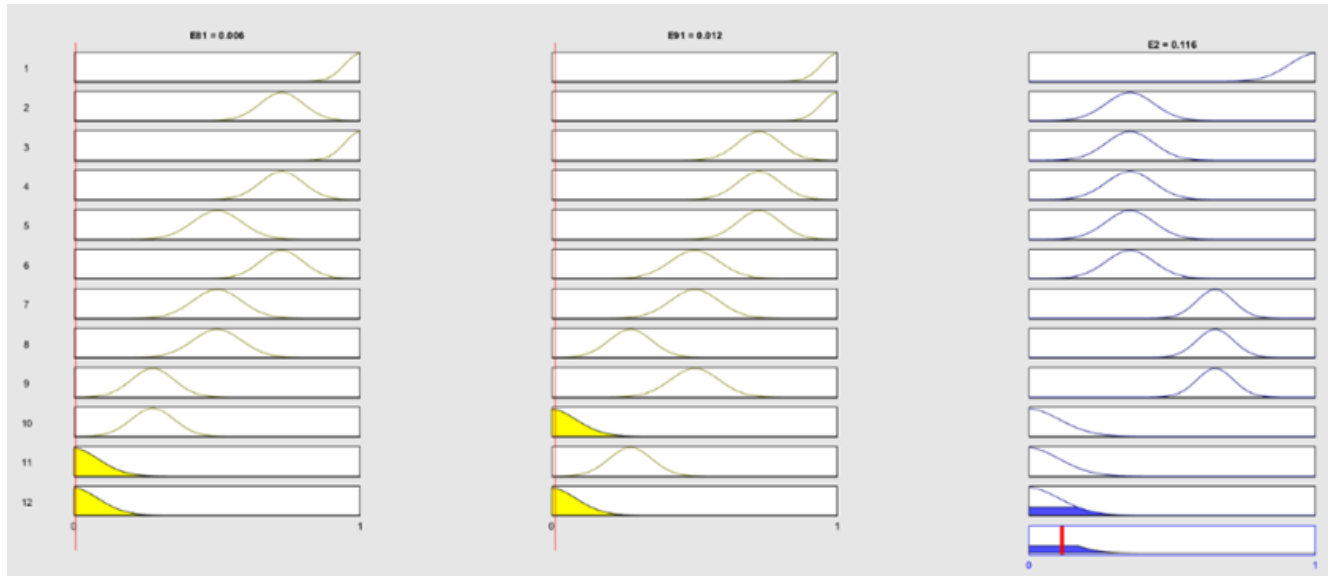

\section{Figure 6. Efficiency evaluation of the HR subsystem of JSC "Ukreximbank"}

For PJSC "First Ukrainian International Bank", the positive data in the $E_{1}$ efficiency block is the bank's level of efficiency and net interest margin. Block $E_{2}$ has a critically low level of efficiency as shown by the net income to personnel costs. High level of involvement of the bank in digitalization in Block $E_{3}$ is efficiency of information-intellectual subsystem.
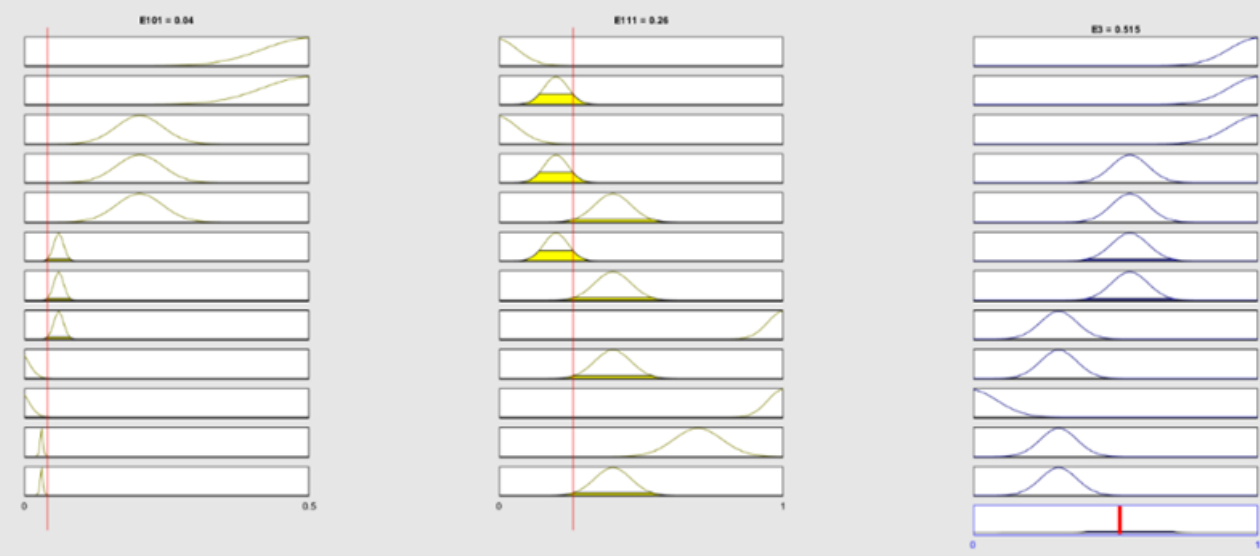

Figure 7. PJSC “First Ukrainian International Bank" information-intellectual subsystem efficiency evaluation

TASCOMBANK JSC in Block $E_{1}$ showed a good result on the net interest margin indicator. Block $E_{2}$ has shown that the performance of the HR subsystem is critically low. Information-intellectual subsystem efficiency block $E_{3}$ has shown that the marketing efficiency ratio is average. 
The results of the model for PJSC "Trust-capital" reflect that in block $E_{1}$ a good result was shown by the net interest margin and average assets balances.

For Privatbank, the positive data in the $E_{2}$ efficiency block is the profitability of the bank's equity and the level of efficiency of the bank. In $E_{2}$ the level of net income per employee is high, and in block $E_{3}$ the bank digitalization involvement rate is very high.

Analytical studies of the conditions of financial and economic subsystem of different banks (See Table. 1) it is possible to conclude that the percentage of banks' margin is at a sufficient level, which shows us the success and skill of management of the studied banks and banks efficiency level indicators are within a sufficient level.

It is possible to make general conclusions that at the present time the financial and economic sustainability of such banks as Trust Capital and PJSC TASCOMBANK for the sustainable development of banks is at a low level with a potential transition to the average level.

Analytical studies of the conditions of the personnel subsystem of different banks (See Table 1) show that the level of profitability from an employee is low, which does not allow to have dynamic growth in other blocks of subsystems and the level of bank expenses per employee is low, which hinders the increase in the efficiency of profitability indicators per employee.

The overall conclusion of the human resources subsystem is at a very low level, which hinders the development of other subsystems for the sustainable development of banks.

Modeling of the information-intellectual subsystem provides such results for the studied banks (See Table 1) that the ratio of bank involvement in digitalization among the analyzed banks is at a high level, which shows the beginning of transformations in banks in the field of information technology. The efficiency and involvement of banks in marketing to promote information about the services and new products of the bank are low.

The results of the analytical calculations and the fuzzy modeling coincide, which speaks in favor of the efficiency of the developed model. Analytical studies of the developed model indicate that the bank management needs to carry out strategic planning in the area of information-communication technologies and their intellectualization, which will ensure efficiency of the banks sustainable development. Particular attention should be paid to improving the efficiency of the HR block, as financial institution staff is largely a key contributor to sustainable development, staff turnover which may be related to employee dissatisfaction with working conditions and everyday life, which are closely linked to the fluctuations in performance development of the bank.

\section{Modern methodologies for designing banks sustainable development}

The introduction of modern design methodologies for different classes of information and management systems is an orientation to the introduction of the concept of sustainable development, the use of methodology for evaluating the efficiency of bank subsystems and the process of digitalization.

The main reason for the transition to new design methodologies, as a rule, is to shorten the life of the work, reduce errors in the development of a new product, multitask, reliability and modern age.

The most important factors that determine the current state of development of design methodologies are: 
- UML modeling. Object-oriented language gives you the ability to clearly describe the system from different perspectives and for different purposes and audiences;

- Code reuse. The concept of code reuse was a response to the critical requirement of controlling the lifecycle of software systems and reducing labor costs;

- System control version. Version control is a configuration management, one of which is version management;

- Capability maturity model. The Initiative for the Harmonization and Integration of Key Processes and Systems Engineering Actions has enabled an integrated approach to improve CMM processes;

- Agile software development approaches. Focused on evolution, rapid return and close engagement of participants with minimization of written documentation, a close link between specification and implementation processes (Ward Cunningham, 2001).

The prospects for developing the banks sustainable development design methodologies are linked with the increase of the abstraction level for developing new banking products as well as increasing product reliability to bring the developer and user closer together as a specialist in a particular subject area.

\section{Development of structure of complex of management of decision-making system and its digitalization}

In the conceptual model, the study of sustainable bank development consists of the following modules:

- Analysis of possible disturbances. A module that is responsible for handling factors that may disrupt the functionality or actions of the bank, leading to the prospect of losing a balanced, equilibrium, predicted state.

- Define management goals and missions. Module of management complex with knowledge base in which strategic indicators, principles, favorable scenarios of bank development are stored.

- Formation of competences. A module used to assimilate and search for knowledge, skills and ways of working in specific situations to solve practical and theoretical problems.

- Bank stability module. A module in which systematic monitoring of the bank's stability is carried out to maintain all sustainability indicators in the proper development under the bank's strategy.

The dynamism of change and the emergence of new perturbations require an information system of continuous monitoring and control of decision-making that will ensure the sustainable development of banks. Due to effective monitoring and regular review of risks in management processes, information about the state of the object and internal and external factors is obtained and processed to identify perturbations and risks that determine management actions.

\section{Conclusions}

1. The article proposes the Concept of research and management of the processes of the banks sustainable development to solve the problems how to improve the efficiency of banks as well as their competitiveness in the financial services market. The concept is based on the general principles of development of bank formation, which include the basic principles of integrity, sustainability, digitalization and structural logic of linkages of elements 
and the banking system as a whole. This approach allowed us to implement a modified closed-loop banking product development cycle in an integrated banking environment that is interconnected between participants in monetary transactions.

2. A fuzzy model is proposed for evaluating the efficiency of banks sustainable development, which embodies a fuzzy knowledge of the object of identification that is expertly constructed, as well as a mechanism for drawing a logical conclusion on the basis of the mathematical apparatus of fuzzy set theory. The structure of analysis of groups of evaluation indicators includes financial, economic, HR, information subsystems of the bank, which form an integral logical indicator of evaluation of the bank's performance depending on the periods of analysis of the bank's activity, as well as the results of the implementation of a closed structural and logical cycle.

3. The banking closed production and technological cycle is developed which consists in repeated use of the resource, which in combination with information technologies provide the necessary quality for the banking product. The process of introducing a closed production and technological cycle in the banking sector is an innovative trend, which envisages the functioning of banks on the basis of ensuring rational consumption of bank resources and minimizing the integral influence of processes by creating new banking products.

4. On the basis of the proposed concept of research and management of the processes of banks sustainable development, the developed economic and mathematical model of evaluating the banks sustainable development and taking into account the features and patterns of activity of the banks in Ukraine identified directions for improving management decisions for sustainable development of banks.

A promising direction of research in the area of modeling banks sustainable development is further development of economic and mathematical models for assessing bank subsystems and focusing on building models for adaptive automatic banking management systems.

\section{References}

Matviychuk, V.A. (2007). Modeling Economic Processes Using Fuzzy Logic Methods. (Monograph). Kyiv: KNEU. [in Ukrainian].

National Bank of Ukraine. (2019). Main indicators of bank activity. Observational statistics. [Electronic resource]. Retrieved from https://bank.gov.ua/statistic/supervision-statist/datasupervision\#4. [in Ukrainian].

Olkhovska, O. L. (2011). Modeling the Financial Condition of an Insurance Company. (Dissertation). Kyiv: KNEU. [in Ukrainian].

Ustenko, S. V. (2008). Modeling of processes of functioning and development of high-tech production systems (Unpublished doctoral dissertation). Kyiv: KNEU. [in Ukrainian].

Ward Cunningham. (2001). Flexible Software Development Manifesto. [Electronic resource]. Retrieved from http://agilemanifesto.org/. [in English].

Zade, L. A. (1976). The concept of a linguistic variable and its application in making approximate decisions. Kiev: Peace. [in English]. 